\title{
Pengenalan Pola Sinyal Electromyography(EMG) pada Gerakan Jari Tangan Kanan
}

\section{WAHYU MULDAYANI ${ }^{1}$, ARIZAL MUJIBTAMALA NANDA IMRON ${ }^{1}$, KHAIRUL ANAM $^{1}$, SUMARDI ${ }^{1}$, WIDJONARKO ${ }^{1}$, ZILVANHISNA EMKA FITRI ${ }^{2}$}

\author{
${ }^{1}$ Teknik Elektro Fakultas Teknik Universitas Jember, Indonesia \\ ${ }^{2}$ Teknologi Informasi Politeknik Negeri Jember, Indonesia \\ Email: wahyumuldayani.teknik@unej.ac.id
}

Received 20 Februari 2020 | Revised 27 April 2020 | Accepted 3 Mei 2020

\begin{abstract}
ABSTRAK
Sinyal EMG merupakan salah satu sinyal yang dapat digunakan untuk memberikan perintah pada kursi roda listrik. Sinyal EMG yang digunakan diambil dari sinyal otot fleksor dan ekstensor yang berada di tangan kanan. Sinyal tersebut diambil menggunakan sensor Myo Armband. Klasifikasi sinyal EMG diambil dari pergerakan jari yang mewakili perintah gerak yaitu jari kelingking untuk bergerak maju, jari manis untuk berhenti, jari tengah untuk belok kanan dan jari telunjuk untuk belok kiri. Setiap sinyal EMG diekstraksi fitur untuk menentukan karakteristik sinyal sehingga fitur yang diperoleh adalah Average Absolute Value, Root Mean Square, Simple Integral Square, EMG Simple Variant and Integrated EMG. Kemudian fitur tersebut digunakan sebagai input dari metode klasifikasi Artificial Neural Network Backpropagation. Jumlah data latih yang digunakan adalah 800 data sedangkan data uji yang digunakan adalah 200 data. Tingkat keberhasilan proses klasifikasi ini sebesar $93 \%$.
\end{abstract}

Kata kunci: electromyogram, artificial neural network, klasifikasi sinyal, tangan kanan, Myo Armband.

\begin{abstract}
EMG signal is one of the signals that can be used to give orders to electric wheelchairs. The EMG signal used is taken from the flexor and extensor muscle signals in the right hand. The signal is taken using the Myo Armband sensor. The EMG signal classification is taken from the movement of the finger which represents the command of motion ie the little finger to move forward, ring finger to stop, middle finger to turn right and index finger to turn left. Each EMG signal is extracted features to determine the signal characteristics so that the features obtained are Average Absolute Value, Root Mean Square, Simple Integral Square, EMG Simple Variant and Integrated EMG. Then the feature is used as input from the Backpropagation classification method. The amount of training data used is 800 data while the test data used is 200 data. The success rate of this classification process is $93 \%$.
\end{abstract}

Keywords: electromyogram, artificial neural network, signal classification, right hand, Myo Armband. 
Muldayani, dkk

\section{PENDAHULUAN}

Kelumpuhan adalah suatu penyakit yang dapat membatasi ruang gerak penderitanya, banyak hal yang dapat digunakan untuk membantu menambah ruang gerak penderitanya, baik secara konvensional maupun modern. Secara konvensional, alat bantu untuk penderita kelumpuhan dapat berupa tongkat, kruk, walker, tripod dan kursi roda konvensional yang digerakkan dengan cara didorong. Alat bantu konvensional dapat digunakan oleh penderita kelumpuhan sesuai dengan tingkat kelumpuhan yang dideritanya. Dewasa ini banyak dikembangkan alat bantu untuk penderita kelumpuhan yang dapat memudahkan penderitanya, salah satunya adalah kursi roda elektrik.

Kursi roda elektrik untuk penderita kelumpuhan terdapat beragam jenis, misalnya kursi roda elektrik yang digerakkan menggunakan pergerakan bahu, dimana perintah gerak kursi roda diberikan melalu perbedaan impedansi pada bahu kanan dan kiri, atau dapat disebut juga bioelectrical impedance (Imron, dkk, 2016). Sinyal electrooculogram (EOG) juga dapat dimanfaatkan sebagai pemberi perintah kepada kursi roda elektrik, perintah yang diberikan melalui kedipan mata dengan sebuah elektroda EOG yang diletakkan pada mata kiri (Huang, dkk, 2018). Selain hal tersebut juga terdapat kursi roda elektrik yang digerakkan oleh sinyal otot atau electromyography (EMG). Sinyal EMG dapat diklasifikasikan dengan berbagai cara, misalnya dengan dua sinyal EMG yang dihasilkan dari otot fleksor pada tangan kanan dan kiri, dua sinyal tersebut memungkinkan untuk klasifikasi sederhana, misalkan untuk klasifikasi perintah kursi roda untuk maju, belok kanan dan belok kiri. Cara yang dilakukan untuk mendeteksi pemberian perintah gerak adalah dengan cara threshold, threshold bekerja ketika terdapat perubahan sinyal EMG, jika besarnya sinyal lebih dari batas threshold maka dapat di deteksi sebagai perintah gerak (Imron, dkk, 2019). Sinyal EMG dari wajah juga dapat digunakan untuk memberikan perintah gerak kepada kursi roda elektrik, sinyal EMG diambil dari otot zygomaticus dan otot transversus (Jang, dkk, 2016). Selain untuk kendali penuh atas pergerakan kursi roda, pemanfaat sinyal EMG juga dapat digunakan untuk kursi roda dengan sistem power-assisted. Sistem tersebut akan bekerja jika mendeteksi perubahan pada sinyal EMG yang diletakkan pada tangan kanan (Oonishi, dkk, 2010).

Klasifikasi yang lebih komplek dapat dilakukan dengan menambah jumlah sinyal sebagai acuan untuk proses klasifikasi. Perangkat Myo Armband dapat digunakan sebagai alat untuk mengambil sinyal EMG pada otot lengan dengan delapan sinyal output. Pada penerapannya Myo Armband dapat digunakan sebagai klasifikasi pergerakan tangan untuk klasifikasi Bahasa isyarat Indonesia. Penelitian tersebut menggunakan empat ekstraksi fitur untuk mengambil karakteristik sinyal EMG, sedangkan untuk klasifikasinya menggunakan algoritma Naïve Bayes, algoritma tersebut dapat mengkasifikasikan dengan input beberapa kombinasi dari ektraksi fitur Mean Absolute Value (MAV), Root Mean Square(RMS), Simple Square Integral (SSI) dan Variance of EMG (VAR) (Rahayuningsih, dkk, 2018). untuk meningkatkan akurasinya ditambahkan sensor Leap motion (Khamid, dkk, 2017). Penelitian lain yang berkaitan dengan sinyal EMG sebagai kontrol otomatis juga dilakukan menggunakan algoritma Naïve Bayes, hasil yang didapat adalah mendeteksi gerakan tangan berupa menggenggam, jari terbuka, pergelangan digerakkan ke arah dalam, pergelangan digerakkan ke arah luar dan keadaan santai. Sedangkan ekstraksi fitur yang digunakan adalah Peak Number, Mean Absolute Value (MAV), Calculate Willison Amplitude (WAMP) dan Root Mean Square (RMS) (Falih, dkk, 2017).

Selain menggunakan algoritma Naïve Bayes, terdapat juga algoritma jaringan syaraf tiruan (neural network) yang digunakan untuk klasifikasi, dengan gerakan uji yang sama, yaitu menggenggam, jari terbuka, pergelangan digerakkan ke arah dalam, pergelangan digerakkan 
ke arah luar dan keadaan santai menghasilkan pengenalan klasifikasi yang lebih baik, dengan fitur ekstraksi yang berbeda (AlKhazzar, dkk, 2018). Algoritma jaringan syraf tiruan juga diterapkan pada gerakan membuka jari dengan enam kombinasi dan dapat mengklasifikasikan gerakannya (He, dkk, 2017). Aplikasi lain yang juga memanfaatkan sinyal EMG adalah robot lengan, robot tersebut digerakkan menggunakan delapan sinyal output dari sinyal EMG pada lengan bawah, dengan algoritma jaringan syaraf tiruan dapat mengklasifikasikan gerakan jari menggenggam dan membuka (Kurniawan \& Pamungkas, 2018). Penerapan lain sinyal EMG juga dilakukan untuk menggerakkan robot lengan, dengan menempatkan sensor EMG pada persendian lengan kanan (Artemiadis, dkk, 2010). Penelitian-penelitian tersebut menunjukkan hasil yang lebih baik ketika menggunakan algoritma jaringan syaraf tiruan. Penelitian ini menerapkan algoritma tersebut dengan ekstraksi fitur yang berbeda sebagai klasifikasi sinyal EMG pada pergerakan jari di tangan kanan.

\section{METODE}

Sinyal EMG yang digunakan merupakan sinyal hasil dari gerakan melipat ke dalam pada jari kelingking, jari manis, jari tengah dan jari telunjuk seperti pada Gambar 1, dipilihnya keempat jari tersebut karena gerakan tersebut merupakan gerakan yang paling sedikit mengeluarkan energi pada otot tangan. Sehingga kursi roda elektrik nantinya dapat digunakan lebih banyak kalangan, khususnya penderita kelumpuhan. Gerakan jari-jari tersebut memanfaatkan otot pada lengan bagian bawah. Kelompok otot tersebut adalah otot flexsordan extensor, sehingga sensor Myo Armband diletakkan tepat pada kelompok otot tersebut.

Proses klasifikasi sinyal EMG dimulai dari pengambilan data sinyal EMG menggunakan sensor Myo Armband dengan sinyal output sebanyak delapan sinyal yang diinisialisasikan sebagai channe/ 1 / $\mathrm{CH} 1$ sampai dengan channe/ 8 / CH8 , selanjutnya masing-masing dari sinyal tersebut dicari karakteristiknya menggunakan ekstrasi fitur Mean Absolute Value (MAV), Root Mean Square (RMS), Simple Square Integral (SSI), Variance of EMG (VAR) dan Integrated EMG (IEMG). Cara mencari karakteristiknya adalah dengan memasukkan data masing-masing sinyal dari $\mathrm{CH} 1$ sampai dengan $\mathrm{CH} 8$ ke dalam perhitungan lima ekstraksi fitur tersebut, sehingga output dari ekstraksi fitur tersebut menghasilkan total empat puluh sinyal dalam satu gerakan jari, sinyal-sinyal tersebut digunakan sebagai inputalgoritma Artificial Neural Network, dalam hal ini Artificial Neural Network yang digunakan adalah Artificial Neural Network dengan Backpropagation. Sedangkan output Artificial Neural Network berupa klasifikasi perintah gerak maju, berhenti, belok kanan dan belok kiri. Tahapan tersebut dapat dilihat pada Gambar 2.

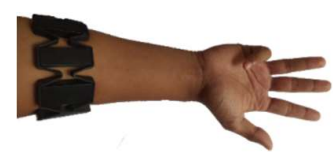

(a)

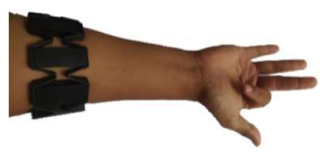

(c)

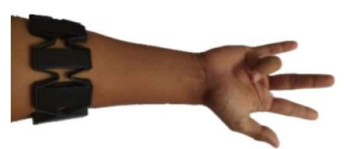

(b)

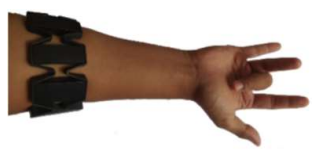

(d)

Gambar 1. Gerakan Jari, (a) Jari Kelingking, (b) Jari Manis, (c) Jari Telunjuk, (d) Jari Tengah 


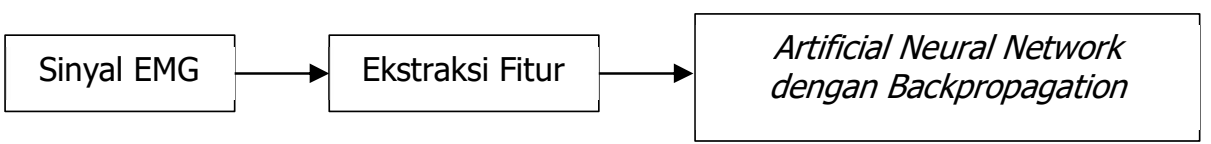

\section{Gambar 2. Proses Klasifikasi}

\subsection{Sinyal EMG}

Sinyal EMG didapat dari empat gerakan jari, yaitu gerakan jari kelingking, jari manis, jari tengan dan jari telunjuk yang masing-masing digerakkan melipat ke dalam. Sampling sinyal yang digunakan pada sensor Myo Armband sebesar 200 Hz, Gambar 3 sampai dengan Gambar 6 merupakan contoh perekaman sinyal EMG pada masing-masing gerakan jari, setiap perekaman menghasilkan delapan sinyal yang diinisialisasi dengan channe/ 1 / CH1 sampai dengan channe/8 / CH8 dalam grafik tersebut. Sinyal yang ditampilkan pada Gambar 3 sampai dengan Gambar 6 merupakan sinyal dari perekaman raw data secara langsung dan disajikan dalam grafik dengan rentang waktu 1,5 detik. Masing-masing sinyal tersebut dilakukan ekstraksi fitur untuk mengetahui karakteristiknya.
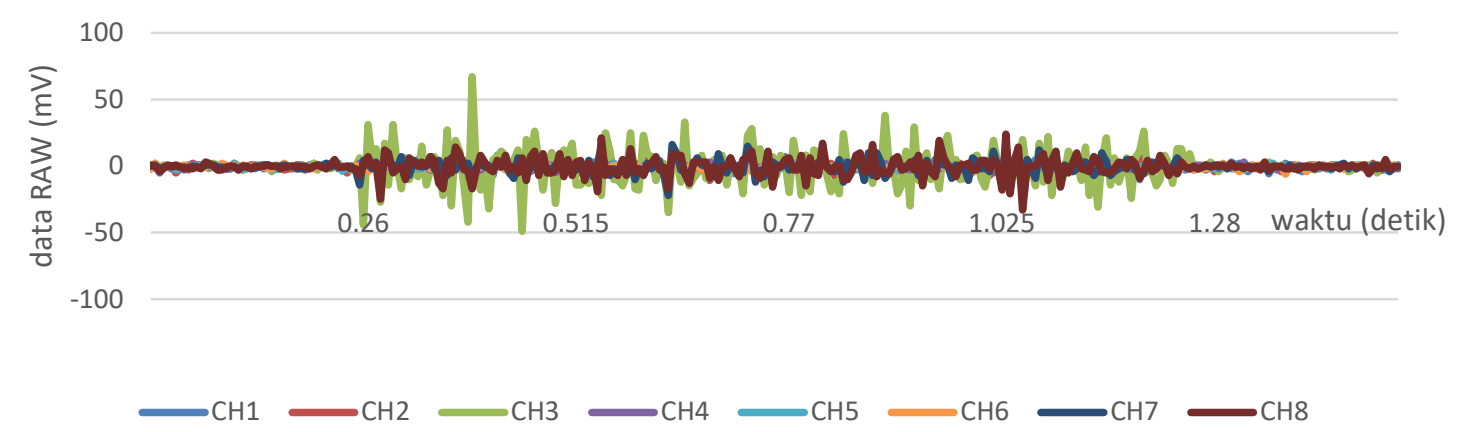

Gambar 3. Sinyal EMG Gerakan Jari Kelingking

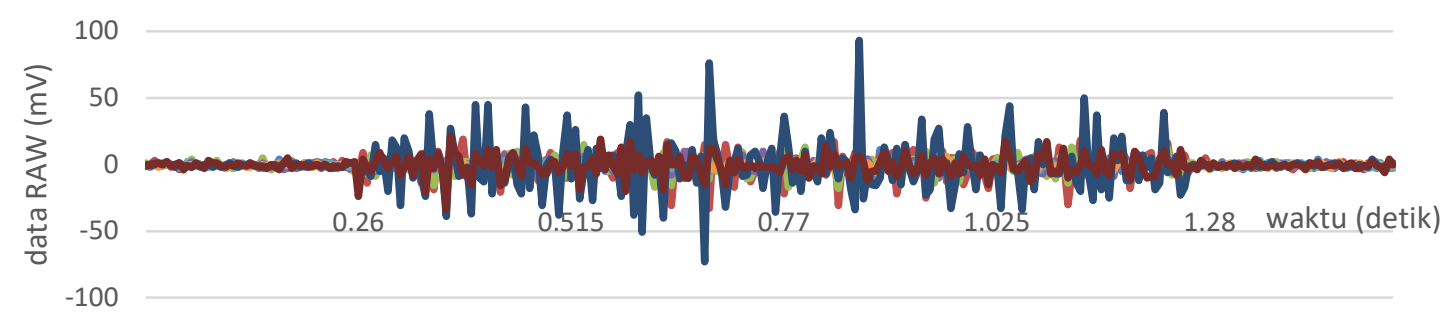

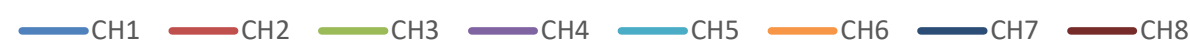

Gambar 4. Sinyal EMG Gerakan Jari Manis 
Pengenalan Pola Sinyal Electromyography(EMG) pada Gerakan Jari Tangan Kanan

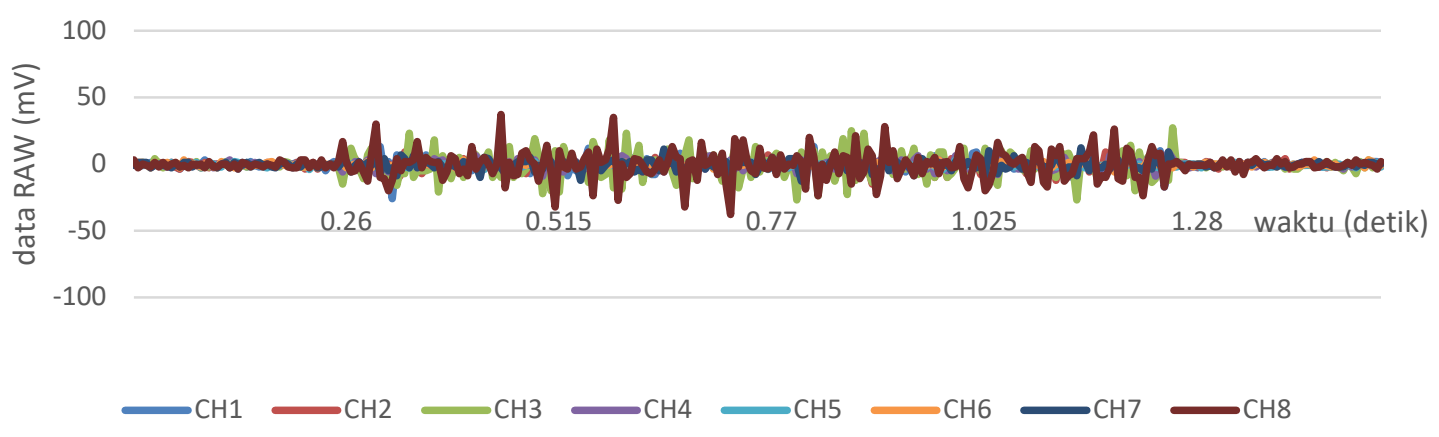

Gambar 5. Sinyal EMG Gerakan Jari Tengah

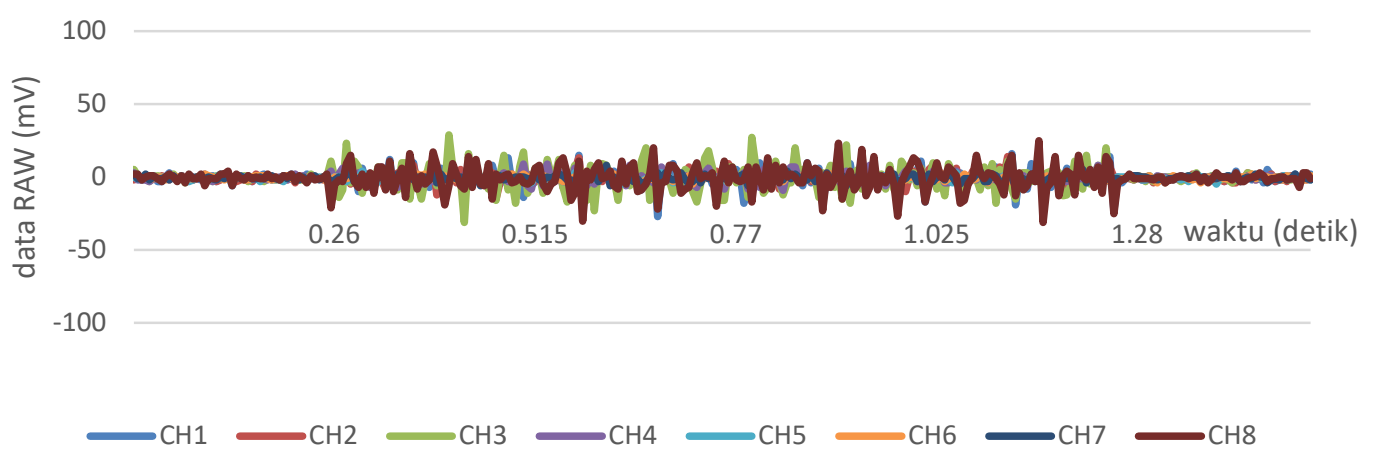

Gambar 6. Sinyal EMG Gerakan Jari Telunjuk

Inisialisasi data training neural network dibagi menjadi empat, yang pertama untuk target training perintah gerak maju merupakan data yang diambil dari data hasil ekstraksi sinyal EMG gerakan jari kelingking, yang kedua untuk target training perintah berhenti merupakan data yang diambil dari data hasil ekstraksi sinyal EMG gerakan jari manis, yang ketiga untuk target training perintah gerak belok kanan merupakan data yang diambil dari data hasil ekstraksi sinyal EMG gerakan jari tengah dan untuk target training perintah gerak belok kiri merupakan data yang diambil dari data hasil ekstraksi sinyal EMG gerakan jari telunjuk. Sehingga ketika terdapat gerakan melipat kedalam pada jari kelingking dapat diinisialisasikan sebagai perintah gerak maju, begitu juga untuk perintah gerak belok kanan, belok kiri dan berhenti yang masing-masing merupakan inisialisasi dari gerakan jari tengah, jari telunjuk dan jari manis.

\subsection{Ekstraksi Fitur}

Ekstraksi fitur merupakan cara yang dapat digunakan untuk mendapatkan lebih banyak informasi dari sinyal, terdapat beberapa macam ekstraksi fitur di antaranya time domain features (Arief, dkk, 2015), frequency domain features dan time-frequency domain features (Pour, 2018). Penelitian ini menggunakan ekstraksi fitur time domain dikarenakan sinyal yang diolah merupakan sinyal langsung hasil perkamanan sinyal EMG.

\subsubsection{Mean Absolute Value (MAV)}

Ekstraksi fitur MAV merupakan rata-rata dari penjumlahan mutlak sinyal yang berurutan dan merupakan salah satu ekstraksi fitur yang sering digunakan, nilai MAV dapat dihitung dengan Persamaan (1) 


$$
M A V=\frac{1}{N} \sum_{k=1}^{N}\left|x_{k}\right|
$$

\subsubsection{Root Mean Square (RMS)}

Ekstraksi fitur RMS merupakan perhitungan dari proses acak modulasi amplitudo Gaussian yang berkaitan dengan gaya konstan dan kontraksi non-fatiguing, nilai RMS dapat dihitung dengan Persamaan (2)

$$
R M S=\sqrt{\frac{1}{N} \sum_{k=1}^{N}\left(x_{k}\right)^{2}}
$$

\subsubsection{Simple Square Integral (SSI)}

Ekstraksi fitur SSI dari snyal EMG mewakili penjumlahan dari nilai kuadrat amplitudo sinyal EMG pada domain waktu, nilai SSI dapat dihitung dengan Persamaan (3)

$$
S S I=\sum_{k=1}^{N}\left(x_{k}\right)^{2}
$$

\subsubsection{Simple Variance of EMG (VAR)}

Ekstraksi fitur VAR menggambarkan momen orde kedua dari sinyal EMG dan merupakan indeks daya, nilai VAR dapat dihitung dengan Persamaan (4)

$$
V A R=\frac{1}{N-1} \sum_{k=1}^{N}\left(x_{k}\right)^{2}
$$

\subsubsection{Integrated EMG (IEMG)}

Ekstraksi fitur IEMG merupakan penjumlahan nilai absolut dari amplitudo sinyal EMG dalam domain waktu, nilai IEMG dapat dihitung dengan Persamaan (5)

$$
I E M G=\sum_{k=1}^{N}\left|x_{k}\right|
$$

\subsection{Artificial Neural Network Backpropagation}

Algoritma klasifikasi yang digunakan adalah algoritma Artificial Neural Network dengan Backpropagation, dimana input algoritma merupakan sinyal hasil ektraksi fitur, yaitu sebanyak empat puluh input sinyal. Desain Artificial Neural Network yang digunakan dapat dilihat pada Gambar 7, terdapat empat puluh neuron/node pada layer input, dua puluh satu neuron/node pada hidden layer dan empat neuron/node pada layer output sebagai klasifikasinya. Pemilihan jumlah node pada hidden layer dilakukan hanya berdasarkan arsitektur yang cenderung mengecil dari jumlah node pada layer input ke layer output, sehingga dimungkinkan untuk meringankan kerja komputasi pada sistem. Hal tersebut dikarenakan tidak ada aturan baku untuk jumlah node pada hidden layer.

Parameter yang digunakan selama proses training merupakan parameter kecepatan belajar atau learning rate dan batas kesalahan yang dijinkan atau root mean square error, masing masing sebesar 0,3 untuk learning rate dan 0,1 untuk root mean square error. Sedangkan 
data training yang digunakan sebanyak 800 data yang diambil secara langsung menggunakan sensor Myo Armband.

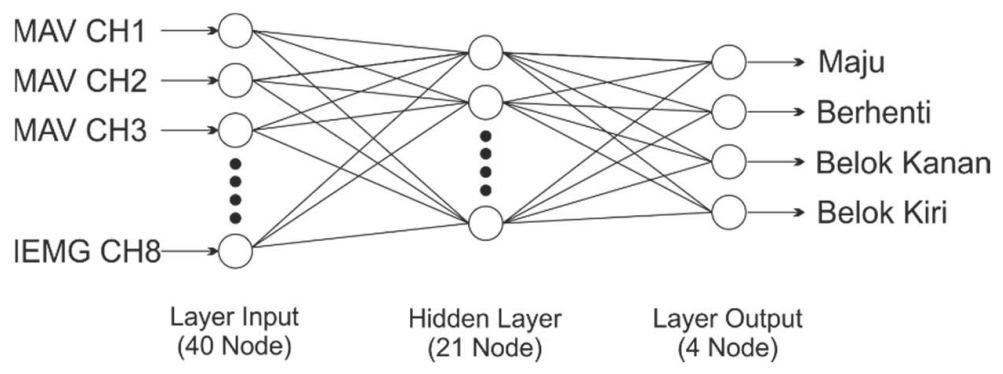

\section{Gambar 7. Arsitektur Neural Network}

\section{HASIL DAN PEMBAHASAN}

Sinyal yang diproses sebagai input algoritma neural network merupakan sinyal hasil ekstraksi fitur dari sinyal-sinyal data raw, sebagai analisisnya disajikan grafik hasil ekstraksi fitur hanya dari satu jari saja, dan proses tersebut juga berlaku untuk data pada perekaman jari yang lain.

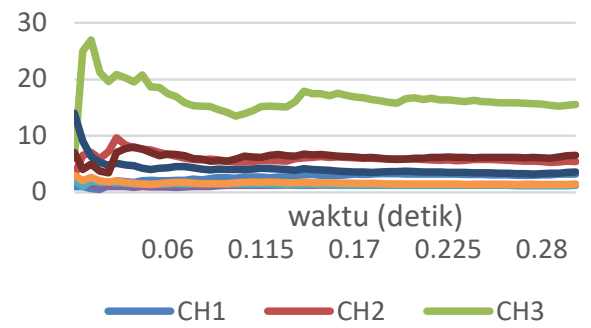

(a)

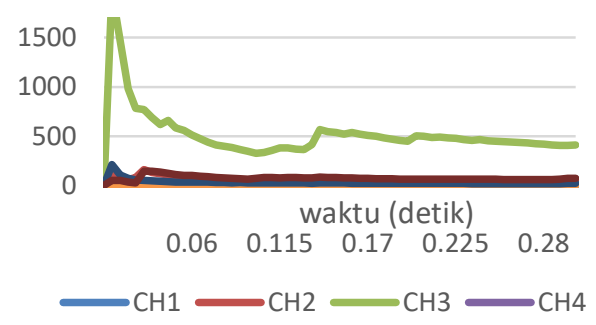

(c)

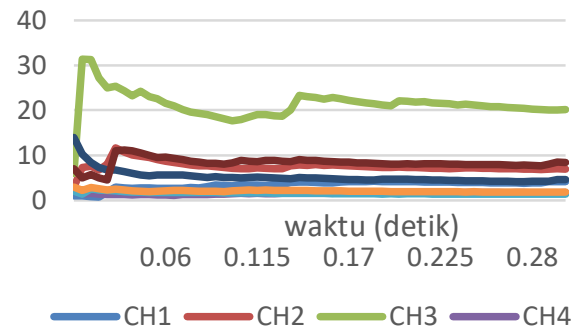

(b)

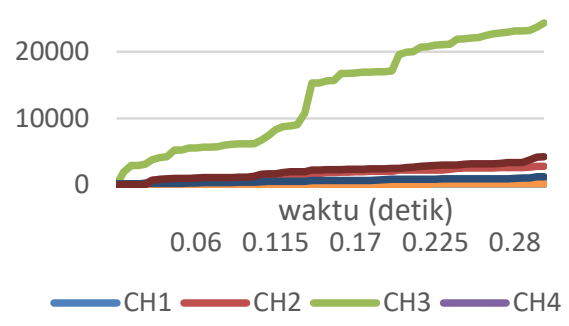

(d)

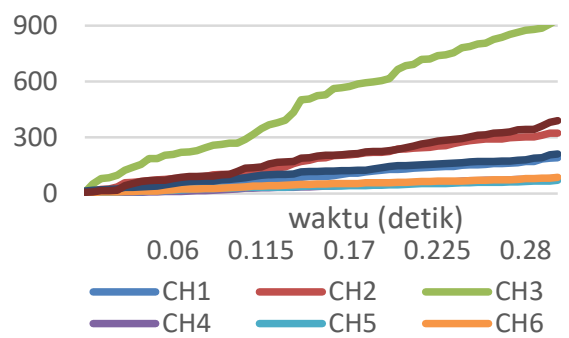

(e)

Gambar 8. Sinyal Hasil Ekstraksi Fitur pada Gerak Jari Kelingking, (a) Ekstraksi FiturMAV, (b) Ekstraksi Fitur RMS, (c) Ekstraksi Fitur VAR, (d) Ekstraksi Fitur SSI dan (d) Ekstraksi Fitur IEMG 
Hasil dari ekstraksi fitur MAV disajikan dalam grafik pada Gambar 8a, dimana grafik tersebut menampilkan sinyal dari hasil ektraksi fitur selama 0,3 detik. Dalam grafik tersebut terdapat delapan grafik yang masing-masing merupakan hasil ekstraksi fitur dari tiap sensor Myo Armband. Hasil ekstraksi fitur MAV, RMS dan VAR, menunjukkan bentuk grafik yang serupa akan tetapi berbeda nilainya, jika dilihat pada grafik hasil ekstraksi fitur MAV pada Gambar 8a, nilai maksimal pada channe/ 3 / CH3 adalah 27, sedangkan pada grafik hasil ekstraksi fitur RMS pada Gambar 8b, nilai maksimal pada channe/ 3 / CH3 adalah 31 dan pada grafik hasil ekstraksi fitur VAR pada Gambar 8c, nilai maksimal pada channe/ 3 / CH3 adalah 200. Persamaan dari ketiga grafik tersebut dapat dilihat dari bentuk keseluruhannya.

Hasil ekstraksi fitur SSI dan IEMG menunjukkan bentuk grafik yang berbeda dengan hasil ekstraksi fitur MAV, RMS dan VAR. Hasil ekstraksi fitur SSI dan IEMG cenderung menunjukkan grafik yang terus meningkat, yang dapat dilihat pada Gambar $8 \mathrm{~d}$ dan $8 \mathrm{e}$. Kedua grafik tersebut menunjukkan bentuk yang serupa dengan grafik yang memiliki nilai tertinggi adalah grafik pada $\mathrm{CH} 3$, di bawahnya merupakan grafik $\mathrm{CH} 8$, dan yang paling bawah adalah grafik dari $\mathrm{CH} 6$.

Tingkat keberhasilan algoritma neural network backpropagation dapat dilihat berdasarkan pola-pola yang dihasilkan dari inputalgoritam tersebut, semakin berbeda polanya maka tingkat keberhasilan semakin tinggi. Cara mendapatkan pola tersebut dengan diambil nilai rata-rata pada tiap ekstraksi fitur pada masing-masing data sinyal EMG. Pola grafik yang ditunjukkan pada ekstraksi fitur MAV pada Gambar 9 dan RMS pada Gambar 10 menunjukkan kesamaan bentuk grafik untuk semua ekstraksi fitur dari sinyal EMG, yang membedakan dari kedua gambar tersebut adalah besar nilainya.

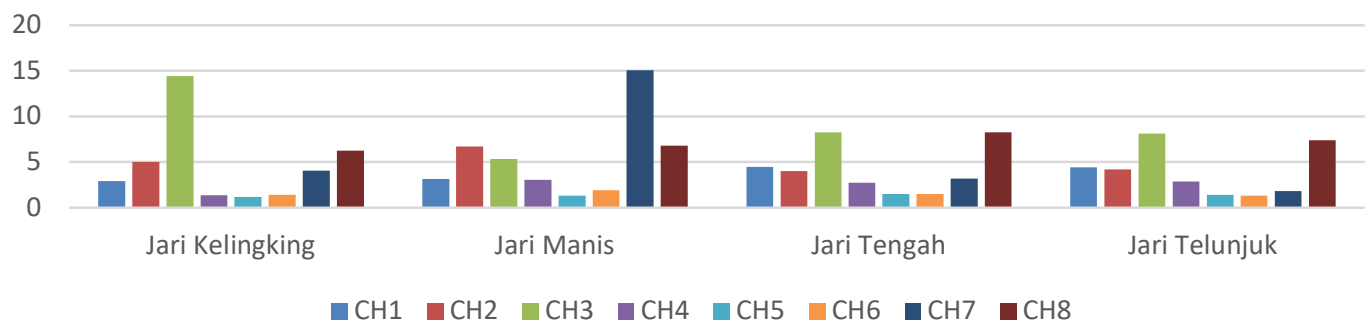

Gambar 9. Pola Grafik dari Rata-Rata Hasil Ekstraksi Fitur MAV

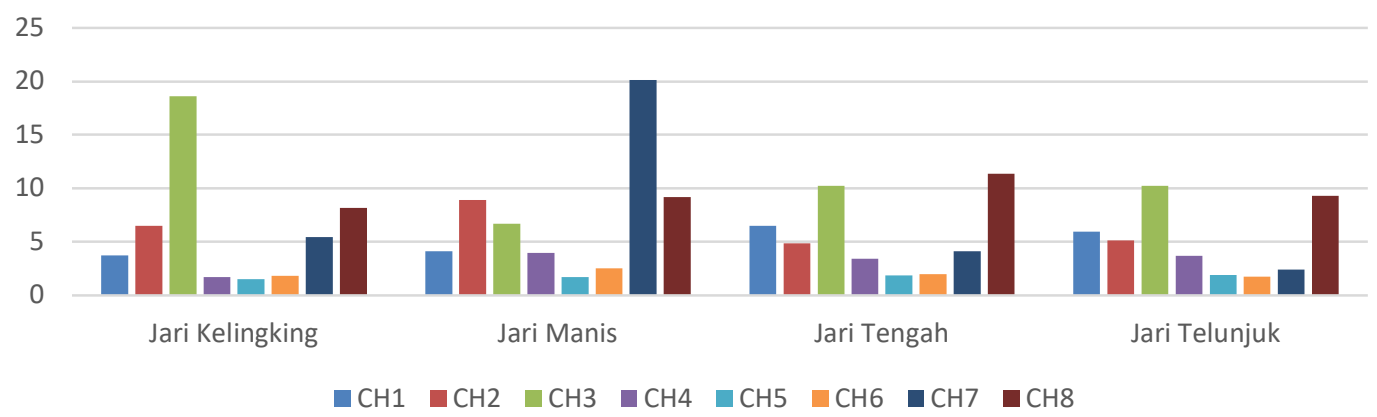

Gambar 10. Pola Grafik dari Rata-Rata Hasil Ekstraksi Fitur RMS 
Pengenalan Pola Sinyal Electromyography (EMG) pada Gerakan Jari Tangan Kanan

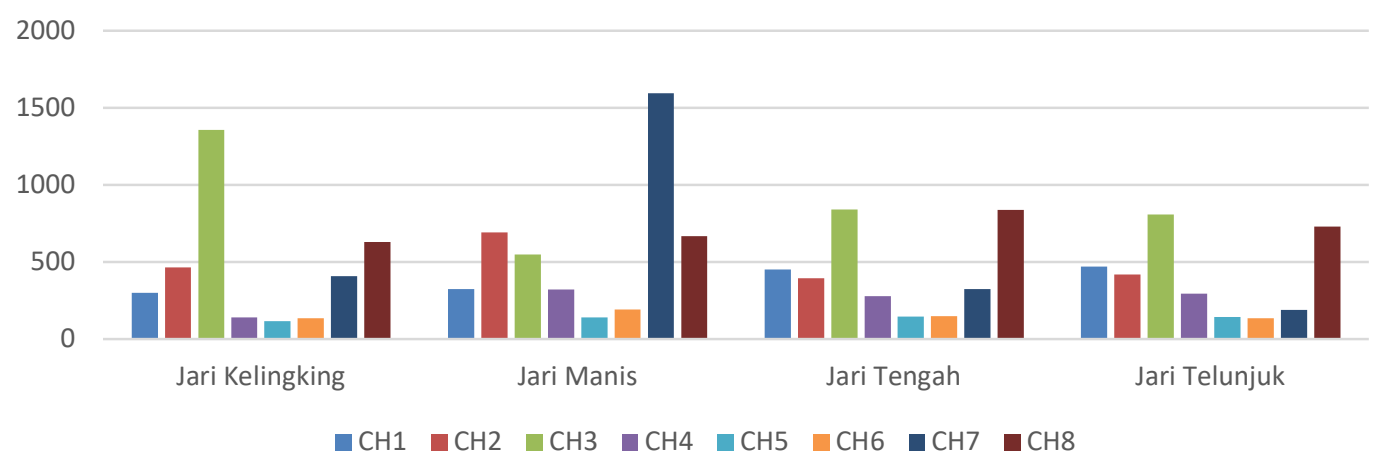

Gambar 11. Pola Grafik dari Rata-Rata Hasil Ekstraksi Fitur IEMG

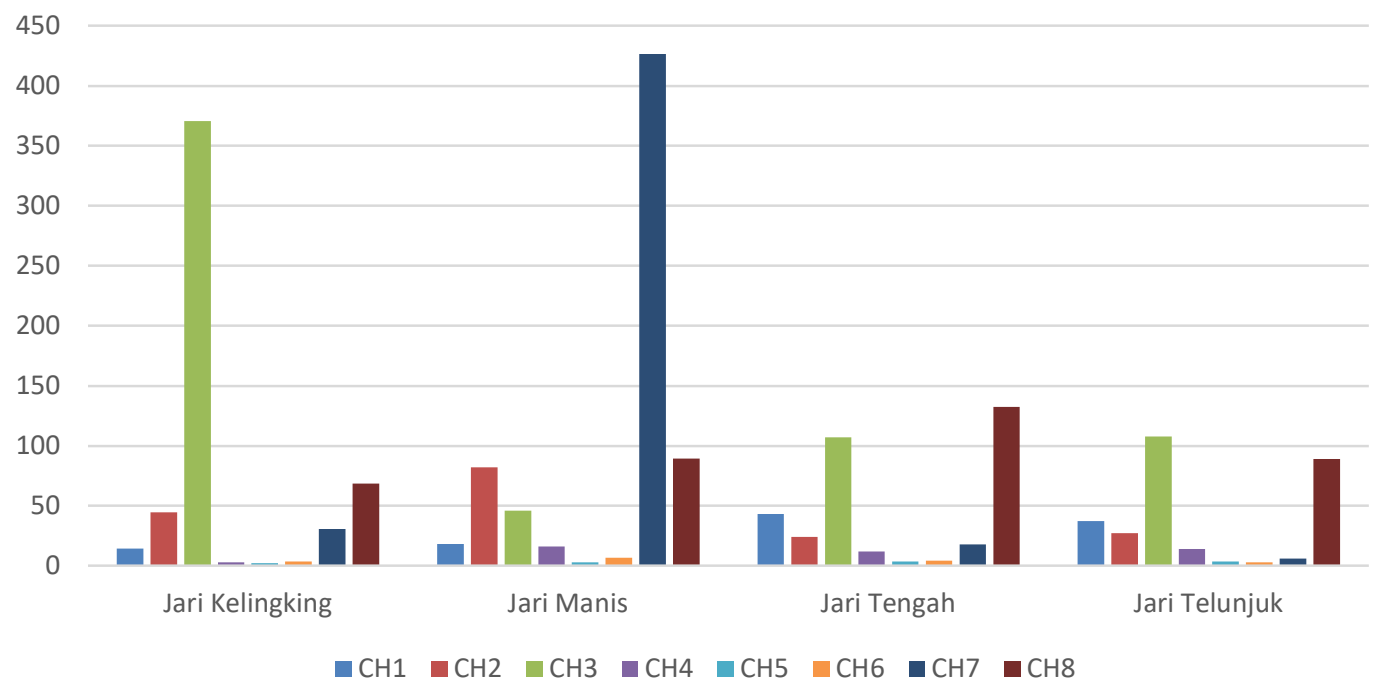

Gambar 12. Pola Grafik dari Rata-Rata Hasil Ekstraksi Fitur VAR

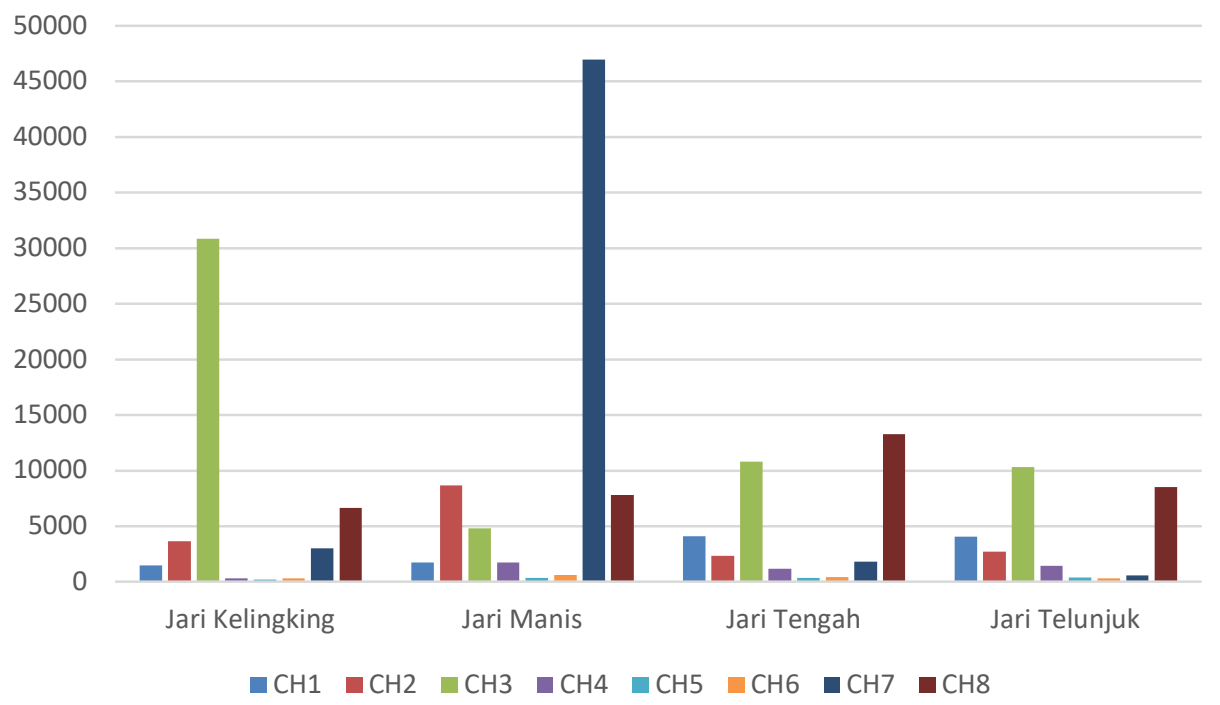

Gambar 13. Pola Grafik dari Rata-Rata Hasil Ekstraksi Fitur SSI

ELKOMIKA - 599 
Grafik pola pada ekstraksi fitur VAR dan SSI pada Gambar 12 dan 13 menunjukkan bentuk yang berbeda. Perbedaan terdapat pada rentan nilainya yang terlalu jauh antara nilai tertinggi dan nilai terendahnya, akan tetapi urutan / pola yang dihasilkan akan tetap sama. Seperti pada pola grafik jari kelingking, akan berurutan dengan nilai rata-rata tertinggi terdapat pada channe/ 3 / CH3, selanjutnya yang lebih rendah berurutan adalah $\mathrm{CH} 8, \mathrm{CH} 2, \mathrm{CH} 7, \mathrm{CH} 1$ dan tiga terbawah merupakan $\mathrm{CH} 4, \mathrm{CH} 5, \mathrm{CH} 6$. Begitu juga untuk grafik rata-rata hasil ekstraksi fitur dari sinyal EMG jari manis, jari tengah dan jari telunjuk.

Pola pada masing-masing ekstraksi fitur menunjukkan grafik yang serupa. Untuk memperkirakan tingkat keberhasilan dalam klasifikasi, hal tersebut tercermin dari tingkat perbedaan pola ekstraksi fitur pada setiap gerakan jari, misalkan pada Gambar 11, pola grafik dari keempat klasifikasi tersebut menunjukkan hasil yang berbeda pada pola grafik jari kelingking dan jari manis, akan tetapi pada grafik jari tengah dan jari telunjuk menunjukkan grafik yang hampir serupa. Grafik pada jari tengah dan telunjuk hanya berbeda pada channel 7 / $\mathrm{CH} 7$ dan channe/ 8 / $\mathrm{CH} 8$ dengan nilai yang lebih rendah, jika diurutkan dari nilai yang terbesar sampai dengan terkecil pada grafik jari tengah berurutan adalah $\mathrm{CH} 3, \mathrm{CH} 8, \mathrm{CH} 1, \mathrm{CH} 2$, $\mathrm{CH} 7, \mathrm{CH} 4, \mathrm{CH} 5$ dan $\mathrm{CH} 6$ sedikit berbeda dengan jari telunjuk yang jika diurutkan dari nilai terbesar dan terkecil adalah $\mathrm{CH} 3, \mathrm{CH} 8, \mathrm{CH} 1, \mathrm{CH} 2, \mathrm{CH} 4, \mathrm{CH} 7, \mathrm{CH} 5$ dan $\mathrm{CH} 6$. Sedikitnya perbedaan antara pola ekstraksi fitur pada jari tengah dan jari telunjuk dapan mempersulit algoritma neural network dalam melakukan klasifikasi.

\section{KESIMPULAN}

Pengujian klasifikasi sinyal EMG dilakukan dengan 200 data untuk total seluruh gerakan dan menunjukkan tingkat keberhasilan sebesar 93\%. Nilai keberhasilan tersebut tercermin dari perbedaan pola pada rata-rata hasil ekstraksi fitur pada setiap gerakan jari. Data training dan pengujian tersebut merupakan data sinyal EMG yang diambil langsung dari orang sehat, sehingga nilai keberhasilan tersebut perlu diuji untuk penderita kelumpuhan sebelum diterapkan pada kursi roda elektrik.

\section{DAFTAR RUJUKAN}

AlKhazzar, A. M., \& Nama Raheema, M. (2018). EMG Signal Classification Using Radial Basis Function Neural Network. Third Scientific Conference of Electrical Engineering (SCEE), (pp. 180-185).

Arief, Z., Sulistijono, I. A., \& Ardiansyah, R. A. (2015). Comparison of five time series EMG features extractions using Myo Armband. International Electronics Symposium (IES), (pp. 11-14).

Artemiadis, P. K., and Kyriakopoulos, K. J. (2010). An EMG-Based Robot Control Scheme Robust to Time-Varying EMG Signal Features. IEEE Transactions on Information Technology in Biomedicine, 14(3), 582-588.

Falih, A. D. I., Dharma, W. A., \& Sumpeno, S. (2017). Classification of EMG signals from forearm muscles as automatic control using Naive Bayes. International Seminar on Intelligent Technology and Its Applications (ISITIA), (pp. 346-351). 
He, S., Yang, C., Wang, M., Cheng, L., \& Hu, Z. (2017). Hand gesture recognition using MYO armband. Chinese Automation Congress (CAC), (pp. 4850-4855).

Huang, Q., et al. (2018). An EOG-Based Human-Machine Interface for Wheelchair Control. IEEE Transactions on Biomedical Engineering, 65(9), 2023-2032.

Imron, A. M. N., Arifin, A., \& Purwanto, D. (2016). Realisasi Kontrol Hirarki Untuk Pengaturan Kecepatan Kursi Roda Elektrik Berdasarkan Subject Intension Menggunakan Bioelectrical Impedance. Seminar Nasional Inovasi dan Aplikasi Teknologi Di Industri (SENIATI), (pp. 6).

Imron, A. M. N., Muldayani, W., \& Sumardi, S. (2019). Perintah Kontrol Gerak Kursi Roda Elektrik Menggunakan Sensor Elektromiograf. Jurnal Rekayasa Elektrika, 15(1).

Jang, G., Kim, J., Lee, S., and Choi, Y. (2016). EMG-Based Continuous Control Scheme With Simple Classifier for Electric-Powered Wheelchair. IEEE Transactions on Industrial Electronics, 63(6), 3695-3705.

Khamid, Wibawa, A. D., \& Sumpeno, S. (2017). Gesture Recognition for Indonesian Sign Language Systems (ISLS) Using Multimodal Sensor Leap Motion and Myo Armband Controllers Based-on Naïve Bayes Classifier. International Conference on Soft Computing, Intelligent System and Information Technology (ICSIIT), (pp. 1-6).

Kurniawan, S. R., \& Pamungkas, D. (2018). MYO Armband sensors and Neural Network Algorithm for Controlling Hand Robot. International Conference on Applied Engineering (ICAE), (pp. 1-6).

Oonishi, Y., Oh, S., and Hori, Y. (2010). A New Control Method for Power-Assisted Wheelchair Based on the Surface Myoelectric Signal. IEEE Transactions on Industrial Electronics, 57(9), 3191-3196.

Pour, M. K. (2018). Encyclopedia of Information Science and Technology (Fourth). United States of America: IGI Global.

Rahayuningsih, I., Wibawa, A. D., \& Pramunanto, E. (2018). Klasifikasi Bahasa Isyarat Indonesia Berbasis Sinyal EMG Menggunakan Fitur Time Domain (MAV, RMS, VAR, SSI). Jurnal Teknik ITS, オ1), 175-180. 